\title{
Safe Concentration of Benzene on Workers at Public Gas Stations around Diponegoro University Semarang, Indonesia
}

\author{
Fatin Zuhra ${ }^{1}$, Abdul Rohim Tualeka ${ }^{1}$, Dimas Triyadi ${ }^{2}$, Pudji Rahmawati ${ }^{3}$, Syamsiar S Russeng ${ }^{4}$, Atjo \\ Wahyu $^{4}$, Ahsan $^{5}$ \\ ${ }^{1}$ Department of Occupational Safety and Health, Faculty of Public Health, Airlangga University, 60155 \\ Surabaya, East Java, Indonesia; ${ }^{2}$ Department of Environmental Health, Faculty of Public Health, \\ Diponegoro University, Semarang, Indonesia; ${ }^{3}$ Department of Development of Islamic Society, State \\ Islamic University Sunan Ampel, Surabaya, Indonesia; ${ }^{4}$ Department of Occupational Safety and Health, \\ Faculty of Public Health, Universitas Hassanudin, Makassar, Indonesia; ${ }^{5}$ Faculty of Nursing, University \\ of Brawijaya, Malang, Indonesia
}

\begin{abstract}
Benzene is a liquid aromatic hydrocarbon compound that is clear, colorless, flammable, and volatile. This study aims to determine safe concentration of benzene at public gas stations workers around Diponegoro University Semarang. This is descriptive, observational, and cross sectional study. A total of 28 workers were then taken as sample. Data was taken in form of primary and secondary data, then analyzed manually through calculation of safe concentration of benzene after determination of weight, body surface of experimental animals, body weight body surface area, breathing rate of workers, benzene concentration, Animal $\mathrm{Km}$, Human $\mathrm{Km}$, highest dose of toxin without causing effect, and reference concentration of benzene for workers.

The measurement of average concentration of benzene in the air showed a value of $0.82 \mathrm{mg} / \mathrm{m}^{3}(0.25 \mathrm{ppm})$. This result is lower than benzene Threshold Limit Value according to Ministry of Manpower Regulation Number 5 of 2018 of $0.5 \mathrm{ppm}$. In contrast, manual calculation of safe concentration of benzene was 0.01 $\mathrm{ppm}$. In conclusion, average value of benzene concentration is not safe for workers. Efforts to control benzene exposure in work environment are needed to ensure workers health such as use of Personal Protective Equipment in form of half mask respirators with organic vapor cartridges, consumption of CYP2E1 enzymes in beef liver and salmon meat, procurement of Golden Phothos or Boston plants, and inspection and regular monitoring of benzene exposure biomarkers in work environment.
\end{abstract}

Keywords: Benzene, Safe Concentration, Workers

\section{Introduction}

Benzene is a liquid aromatic hydrocarbon compound that is clear, colorless, flammable and volatile with a smell like gasoline. Benzene is carcinogenic to humans and associated with an increased risk of

\section{Corresponding Author:}

Abdul Rohim Tualeka

Department of Occupational Safety and Health, Public Health Faculty, Airlangga University, 60115, Surabaya, East Java, Indonesia.

Phone: +62-31-592-0948

Email: abdul-r-t@fkm.unair.ac.id developing lymphatic and hematopoietic cancers, acute myelogenous leukemia and chronic lymphocytic leukemia ${ }^{(1)}$. According to World Health Organization (2010), narcosis with symptoms of headache, drowsiness, confusion, and loss of consciousness is the effect of acute exposure to benzene ${ }^{(2)}$. The effect of chronic exposure to benzene is cancer.

According to Agency for Toxic Substances and Disease Registry, there is a causal relationship between exposure to benzene in workplace as a major cause of increased leukemia. This is supported by National Cancer Institute and Chinese Academy of Preventive Medicine study conducted on 74,828 workers in China exposed 
to benzene. The risk of leukemia increases at average exposure of 10-24 ppm and cumulative exposure of 40$99 \mathrm{ppm} /$ year $^{(3)}$.

The benzene compound has value of Inhalation Reference Concentration for non carcinogenic effects by $3 \times 10-2 \mathrm{mg} / \mathrm{m}^{3}(0.0086 \mathrm{mg} / \mathrm{kg} /$ day $)$ and Cancer Slope Factor for carcinogenic effects by $2.2 \times 10^{-6}-7,8 \times 10^{-6} \mathrm{mg} /$ $\mathrm{m}^{3}$ (0.1-0.34 $\mathrm{mg} / \mathrm{kg} /$ day) that has been determined by Integrated Risk Information System U.S. Environmental Protection Agency ${ }^{(4)}$. The volume of benzene in oil and gas industry functions as an octane-enhancing solvent for gasoline products is about $1-5 \%{ }^{(5)}$. Occupational Safety and Health Standards states that exposure limit in working period is $1 \mathrm{ppm}^{(6)}$. American Conference of Government Industrial Hygienists in 2012 recommended exposure to working period of $0.5 \mathrm{ppm}^{(7)}$. In Indonesia, benzene Threshold Limit Value by Ministry of Manpower Regulation Number 5 of 2018 is $0.5 \mathrm{ppm}^{(8)}$.

Semarang has the highest population growth rate in 2010-2017 at 1.72\%, especially Tembalang and Banyumanik sub-districts at $21.03 \%$ and $14.03 \%(9,10,11)$. High number of population have impact on the use of motorized vehicles that reached 48,663 and 17.121 units $^{(12)}$. It influences increase in fuel demand and availability of public gas stations around Diponegoro University.

The Ministry of Mining and Energy Decree Number 1585/K/32/MPE/1999 concerning Marketing Requirements and Domestic Gasoline and Solar Fuel Types states the gradual elimination of lead and substitution with benzene doesn't reduce the carcinogenic effect because gas stations workers remain directly exposed to these compounds through inhalation, ingestion, and continuous contact with skin ${ }^{(13)}$.

Based on study conducted by Sukaisi (2018), there was an increase in lymphocyte content of public gas stations workers in Medan ${ }^{(14)}$. Content of lymphocyte in leukocytes is around $20-30 \%$. Leukocyte is the most sensitive cell to benzene exposure ${ }^{(15)}$. If leukocytes increase, leukocytosis will occur and trigger lymphocytosis which can cause enlargement of liver, spleen, and glands that are site of lymphocyte formation $^{(16)}$. Winek et al. (1967) in the Agency for Toxic Substances and Disease Registry (2007) stated that fifteen male workers were exposed to benzene with concentration of $>60 \mathrm{ppm}$, causing $80 \%$ of workers have mucous membrane irritation and $67 \%$ have shortness of breath for 3 weeks ${ }^{(3)}$. Thus, safe limits of benzene concentration need to be known.

Dimas Triyadi (2016) showed the measurement of benzene concentration at public gas stations on the highest value of $2.08 \mathrm{ppm}^{(17)}$. This concentration exceeds benzene Threshold Limit Value. It is concluded to be unsafe that creates risk of causing non-carcinogenic and carcinogenic effects. This is supported by study in Korea that showing exposure to benzene in workplace as cause of increase in hematopoietic disease even though workplace environment had been improved ${ }^{(18)}$.

Based on previous study, no safe concentration has been calculated. This calculation is important to ensure the health of workers. Safe concentration of benzene was calculated by using Reference Concentration formula with No Observed Adverse Effect Level adjusting the research data so as not to cause health problems and carcinogenic effects on workers ${ }^{(19)}$. The author calculates the safe concentration of benzene by using Reference Concentration formula with No Observed Adverse Effect Level as safe limit of benzene concentration in workers of public gas stations.

\section{Material and Method}

This study aims to determine safe concentration of benzene at public gas stations workers around Diponegoro University Semarang. This type of study was descriptive, observational, and cross sectional. The population was all workers at four public gas stations by 78 people. The sample was calculated using Slovin formula and proportional random sampling, taken by using a purposive sampling technique and inclusion criteria which resulted into 28 people.

The study began by collecting secondary data and primary data obtained through filling out questionnaires, weighing weight, and measuring concentration of benzene in the air directly inhaled by public gas stations workers with personal dust sampler and coconut shell charcoal. The variables were weight, body surface area of experimental animals, body weight, body surface area, breathing rate of workers, benzene concentration, Animal Km, Human Km, highest dose of toxin without effect, reference and safe concentration of benzene for workers. Data analysis was carried out by using quantitative data analysis manually to determine the safe concentration of benzene. 


\section{Findings}

A. Characteristics and Body Surface Area of Experimental Animals: The experimental animals used was white mice (Rattus norvegicus).

Table 1: Distribution of Characteristics of White Mice

\begin{tabular}{|c|c|c|}
\hline Experimental animals & $\mathbf{W}$ & BSA \\
\hline 1 & 0,1405 & 0,024165 \\
\hline 2 & 0,1405 & 0,024165 \\
\hline 3 & 0,1410 & 0,024223 \\
\hline 4 & 0,1410 & 0,024223 \\
\hline 5 & 0,1395 & 0,024050 \\
\hline 6 & 0,1415 & 0,024165 \\
\hline
\end{tabular}

The body surface area is calculated by using following formula.

$\mathrm{BSA}=0,09 \mathrm{~W}^{0,67}$

B. Characteristics, Body Surface Area, and Workers Respiratory Rate: The characteristics were weight and length of work of workers. The average body weight is $58.57 \mathrm{~kg}$ and length of work is 6.5 hours/day. The average height of workers is the average height of Indonesian men $159 \mathrm{~cm}$. The body surface area and respiratory rate of workers can be calculated using following formula.

1. The surface area of the workers body

$$
\begin{aligned}
\mathrm{BSA} & =\sqrt{\mathrm{W} \cdot h / 3600} \\
\mathrm{BSA} & =\sqrt{\mathrm{W} \cdot h / 3600} \\
& =\sqrt{58,57 \cdot 159 / 3600} \\
& =1,6 \mathrm{~m}^{2}
\end{aligned}
$$

2. Workers' Breathing Rate

$$
\begin{aligned}
\mathrm{BR} & =\frac{5,3 \ln \mathrm{W}-6,9}{24} \\
\mathrm{BR} & =\frac{5,3 \ln \mathrm{W}-6,9}{24} \\
& =\frac{5,3 \ln 58,57-6,9}{24} \\
& =0,6 \mathrm{~m}^{3} / \mathrm{hour}
\end{aligned}
$$

Table 2: Distribution of Characteristics, Respiratory Rate, and Duration of Work of Public Gas Stations Workers around Diponegoro University Semarang

\begin{tabular}{|c|c|c|c|c|c|}
\hline $\begin{array}{c}\text { Number } \\
\text { of sample }\end{array}$ & $\begin{array}{c}\text { W } \\
(\mathbf{k g})\end{array}$ & $\begin{array}{c}\mathbf{h} \\
(\mathbf{c m})\end{array}$ & $\begin{array}{c}\text { BSA } \\
\left(\mathbf{m}^{\mathbf{2}}\right)\end{array}$ & $\begin{array}{c}\mathbf{B R} \\
\left(\mathbf{m}^{\mathbf{3}} / \mathbf{h}\right)\end{array}$ & $\begin{array}{c}\mathbf{t}(\mathbf{h} / \\
\mathbf{d a y})\end{array}$ \\
\hline 28 & 58,57 & 159 & 1,6 & 0,6 & 6,5 \\
\hline
\end{tabular}

The average body surface area and breathing rate of workers are $1.6 \mathrm{~m}^{2}$ and $0.6 \mathrm{~m}^{3} /$ hour.

C. Benzene Concentration: The average concentration of benzene in the air directly inhaled by public gas stations workers around Diponegoro University Semarang is $0.82 \mathrm{mg} / \mathrm{m}^{3}$. The formula and results of conversion from $\mathrm{mg} / \mathrm{m}^{3}$ to $\mathrm{ppm}$ are as follows.

$$
\begin{aligned}
\mathrm{C} & =24,45 \times \mathrm{C}\left(\mathrm{mg} / \mathrm{m}^{3}\right) \div \text { molecular weight } \\
\mathrm{C} & =24,45 \times \mathrm{C}\left(\mathrm{mg} / \mathrm{m}^{3}\right) \div \text { molecular weight } \\
& =24,45 \times 0,82 \mathrm{mg} / \mathrm{m}^{3} \div 78,11 \\
& =0,25 \mathrm{ppm}(<0,5 \mathrm{ppm})
\end{aligned}
$$

The average benzene concentration is lower than benzene Threshold Limit Value. However, the benzene highest concentration reached $2.08 \mathrm{ppm}$. This exceeds Threshold Limit Value permitted in Ministry of Manpower Regulation Number 5 of 2018 by 5 ppm.

D. Animal Km dan Human Km: Determination of safe dosage of toxin in workers begins with calculation of Animal Km and Human Km.

\section{Animal Km}

$$
\text { Animal } \mathrm{Km}=\frac{\mathrm{W} \text { animal }}{\mathrm{BSA} \text { animal }}
$$

Table 3: Animal Km Calculation Results

\begin{tabular}{|c|c|c|c|}
\hline $\begin{array}{c}\text { Experimental } \\
\text { animals }\end{array}$ & W & BSA & Animal Km \\
\hline 1 & 0,1405 & 0,024165 & 5,814194082 \\
\hline 2 & 0,1405 & 0,024165 & 5,814194082 \\
\hline 3 & 0,1410 & 0,024223 & 5,820914007 \\
\hline 4 & 0,1410 & 0,024223 & 5,820914007 \\
\hline 5 & 0,1395 & 0,024050 & 5,8004158 \\
\hline 6 & 0,1415 & 0,024165 & 5,855576247 \\
\hline Average & 0,1407 & 0,024165 & 5,82 \\
\hline
\end{tabular}

The results of Animal $\mathrm{Km}$ are shown in table 3 with the average Animal $\mathrm{Km}$ in white mice of 5.82 .

\section{Human Km}

Human $\mathrm{Km}=\frac{\mathrm{W} \text { human }}{\text { BSA human }}$ 
Table 4: Human Km Calculation Results

\begin{tabular}{|c|c|c|c|}
\hline $\begin{array}{c}\text { Number of } \\
\text { sample }\end{array}$ & W & BSA & $\begin{array}{c}\text { Human } \\
\text { Km }\end{array}$ \\
\hline 28 & 58,57 & 1,6 & 36,6 \\
\hline
\end{tabular}

The results of Human $\mathrm{Km}$ are shown in table 4 with average Human $\mathrm{Km}$ for public gas stations workers around Diponegoro University Semarang of 36.6 .

\section{E. No Observed Adverse Effect Level (NOAEL):}

To find out the safe limits of concentration, No Observed Adverse Effect Level toxicity test needs to be carried out without causing any effects on experimental animals ${ }^{(20)}$. Swaen et al. (2010) stated that No Observed Adverse Effect Level benzene is $3.0 \mathrm{mg} / \mathrm{m} 3$ or $0.022 \mathrm{mg} / \mathrm{kg}$ obtained from following formula ${ }^{(21)}$.

NOAEL benzene $=3,0 \mathrm{mg} / \mathrm{m}^{3}$

$$
\begin{aligned}
\text { NOAEL benzene } & =\frac{3 \times 0,00013 \times 8}{0,1405} \\
& =0,022 \mathrm{mg} / \mathrm{kg}
\end{aligned}
$$

F. Inhalation Reference Concentration: In book Industrial Toxicology and Risk Assessment (2013) (22), the safe limits of reference concentration on workers are calculated using formula from Shaw et al. (2007) as follows.

$$
\mathrm{RfC}=\text { NOAEL } \frac{\text { animal } \mathrm{Km}}{\text { human } \mathrm{Km}}
$$

The benzene Reference Concentration were obtained from No Observed Adverse Effect Level, average Animal Km, and Human Km are as follows.

$$
\begin{aligned}
\mathrm{RfC} & =\text { NOAEL } \frac{\text { animal Km }}{\text { human } \mathrm{Km}} \\
& =0,022 \frac{5,82}{36,6} \\
& =0,003 \mathrm{mg} / \mathrm{kg}
\end{aligned}
$$

G. Safe Concentration of Benzene: In book of Industrial Toxicology and Risk Assessment (2013) ${ }^{(22)}$, safe concentration of benzene was calculated using formula used after obtaining Reference Concentration with No Observed Adverse Effect Level, average body weight, length of time worked, and breathing rate of workers as follows.

$$
\begin{aligned}
\text { Safe C }\left(\mathrm{mg} / \mathrm{m}^{3}\right) & =\frac{(\mathrm{R} f \mathrm{C})(\mathrm{W})}{(\delta)(\mathrm{BR})(t)} \\
\text { Safe C }(\mathrm{ppm})= & \frac{\# m g / m 3 \times 24,45}{\text { molecular weight }} \\
\text { Safe C }\left(\mathrm{mg} / \mathrm{m}^{3}\right) & =\frac{(\mathrm{R} f \mathrm{C})(\mathrm{W})}{(\delta)(\mathrm{BR})(t)} \\
& =\frac{(0,003)(58,57)}{(50 \%)(0,6)(6,5)} \\
& =0,059 \mathrm{mg} / \mathrm{m}^{3} \\
\text { Safe C }(\mathrm{ppm}) & =\frac{\# m g / m 3 \times 24,45}{\mathrm{molecular} \text { weight }} \\
& =\frac{0,059 \times 24,45}{78,11} \\
& =0,01 \mathrm{ppm}
\end{aligned}
$$

Safe concentration of benzene at public gas stations workers around Diponegoro University Semarang was $0.059 \mathrm{mg} / \mathrm{m}^{3}(0.01 \mathrm{ppm})$. These results can be used to compare with benzene Threshold Limit Value permitted by Ministry of Manpower in 2018 and other institutions such as Occupational Safety and Health Standards, American Conference of Government Industrial Hygienists, or National Institute for Occupational Safety and Health then be basis for efforts to control benzene exposure in work environment to be safe for workers.

The average concentration of benzene reached $0.25 \mathrm{ppm}$ and the highest reached $2.08 \mathrm{ppm}$; exceeding benzene Threshold Limit Value. The safe concentration of benzene was calculated based on Reference Concentration with No Observed Adverse Effect Level. In this study, the value of No Observed Adverse Effect Level benzene using white mice was $0.022 \mathrm{mg} / \mathrm{kg}$. The same result was obtained by Swaen et al. (2010) with $0.022 \mathrm{mg} / \mathrm{kg}^{(21)}$. Meanwhile, this result is smaller than Agency for Toxic Substances and Disease Registry (2007) study which states $3 \mathrm{ppm}$ for exposure through inhalation ${ }^{(3)}$. In conclusion, No Observed Adverse Effect Level benzene was safe for workers.

Benzene Reference Concentration obtained from value of No Observed Adverse Effect Level, average Animal Km, and Human $\mathrm{Km}$ is $0.003 \mathrm{mg} / \mathrm{kg} /$ day. This result is smaller than Integrated Risk Information U.S. Environmental Protection Agency in 2003 which was $0.0085 \mathrm{mg} / \mathrm{kg} / \mathrm{day}^{(4)}$. This result is also smaller than study conducted by Salim (2012) and Hayat (2013) which were 0.01 and $0.0086 \mathrm{mg} / \mathrm{kg} / \mathrm{day}^{(24,25)}$. 
The safe concentration of benzene was $0.01 \mathrm{ppm}$. This result is smaller than benzene Threshold Limit Value and limit of benzene exposure set by- Occupational Safety and Health Standards and American Conference of Government Industrial Hygienists by $1 \mathrm{ppm}$ and $0.5 \mathrm{ppm}^{(6,7,8)}$. The safe concentration of benzene in this study can be used as reference to determine the limits of benzene exposure in work environment so that it is safe for workers.

\section{Conclusion}

The average concentration of benzene in the air directly inhaled by public gas stations workers around Diponegoro University Semarang show a value of 0.25 ppm that it is still lower than $0.5 \mathrm{ppm}$ as benzene Threshold Limit Value. Unlike that, the manually calculated safe concentration of benzene was $0.01 \mathrm{ppm}$. Thus, the average value of benzene concentration is not safe for workers. In addition, the highest benzene concentration reached 2.08 ppm; exceeding Threshold Limit Value and safe concentration of benzene. Therefore, efforts to control benzene exposure in the work environment are needed to ensure the health of workers.

Efforts to control benzene exposure recommended are the use of Personal Protective Equipment in form of half mask respirators with organic vapor cartridges to minimize inhalation of benzene exposure in the air, consumption of CYP2E1 enzymes in beef liver and salmon meat to reduce the concentration of benzene in the body, procure Golden Phothos or Boston ornamental plants to absorb and reduce the concentration of benzene in the air, and check and monitor benzene exposure biomarkers periodically in work environment to control benzene concentrations in the $\operatorname{air}^{(23)}$.

Conflict of Interest: All authors have no conflicts of interest to declare.

Source of Funding: This is an article "Safe Concentration of Benzene on Workers at Public Gas Stations around Diponegoro University Semarang" of Occupational Safety and Health Department that was supported by Activity Budget Plans 2019, Faculty of Public Health, Airlangga University.

Ethical Clearance: The study was approved by the institutional Ethical Board of the Public Health Faculty, Diponegoro University.

\section{REFERENCES}

1. National Center for Biotechnology Information. Benzene [Internet]. 2019. p. 1. Available from: https://pubchem.ncbi.nlm.nih.gov/compound/ benzene.

2. World Health Organization. Exposure to Benzene: A Major Public Health Concern. In: Preventing Disease Through Healthy Environments. Geneva: WHO Document Production Services; 2010.

3. Agency for Toxic Substances and Disease Registry. Toxicological Profile for Benzene. ATSDR's Toxicological Profiles. Atlanta: Division of Toxicology and Environmental Medicine; 2007.

4. IRIS U.S EPA. Benzene ; CASRN 71-43-2. 2003;1-43. Available from: https://cfpub.epa. gov/ncea/iris2/chemicalLanding.cfm?substance_ $\mathrm{nmbr}=276$.

5. World Health Organization Europe. Benzene. In: Air Quality Condition. 2nd ed. Copenhagen: WHO Regional Office for Europe; 2000.

6. Occupational Safety and Health Standards (OSHA). Sampling and analytical methods for Benzene monitoring and measurement procedures (Toxic and Hazardous Substances) [Internet]. OSHA Publications. 2019. Available from: https://www.osha.gov/laws-regs/regulations/ standardnumber/1910/1910.1028AppD.

7. Lyon F. IARC Monographs Benzene. 2018;120(October 2017):10-7.

8. Menteri Ketenagakerjaan Republik Indonesia. Peraturan Menteri Ketenagakerjaan Republik Indonesia Nomor 5 Tahun 2018. 2018.

9. Pusat Data dan Informasi. Ringkasan Eksekutif Data dan Informasi Kesehatan Provinsi Jawa Tengah. Jawa Tengah; 2013.

10. BPS Provinsi Jawa Tengah. Jumlah Penduduk dan Laju Pertumbuhan Penduduk Menurut Kabupaten/ Kota di Provinsi Jawa Tengah, 2015, 2016, dan 2017 [Internet]. Indonesia Population Projection 2010-2025. 2018. Available from: https://jateng. bps.go.id/statictable/2017/10/26/1533/jumlahpenduduk-dan-laju-pertumbuhan-pendudukmenurut-kabupaten-kota-di-provinsi-jawatengah-2015-2017.html. 
11. BPS Kota Semarang. Kota Semarang Dalam Angka. Semarang; 2017.

12. BPS Kota Semarang. Banyaknya Kendaraan Bermotor dirinci menurut Jenis Kendaraan, 2012 - 2014 [Internet].

13. BPS Kota Semarang. 2014. Available from: https:// semarangkota.bps.go.id/linkTableDinamis/view/ $\mathrm{id} / 23$.

14. Menteri Pertambangan dan Energi. Keputusan Menteri Pertambangan dan Energi Nomor 1585 K/32/MPE/1999. 1585 Jakarta; 1999 p. 1-2.

15. Sukaisi. Gambaran Limfosit, CD4+ dan CD8+ serta rasio CD4+ : CD8+ pada Pekerja SPBU di Kota Medan. Reprod Health. 2018;3(2):21-9.

16. Effendi DZ. Peranan Leukosit Sebagai Anti Inflamasi Alergik dalam Tubuh. Universitas Sumatera Utara. 2003;1-8.Ramon A. Analisis Paparan Benzena Terhadap Profil Darah pada Pekerja Industri Pengolahan Minyak Bumi. Diponegoro University. Diponegoro Semarang; 2007.

17. Triyadi D, Nurjazuli, Dangiran HL. Analisis Risiko Kesehatan Akibat Paparan Benzene Melalui Inhalasi Pada Petugas Stasiun Pengisian Bahan Bakar Umum (SPBU) di Sekitar Kawasan Diponegoro University Semarang. Kesehat Masy. 2016;4:907-16.

18. Febyan, Arwi Wijaya, Michelle Linardi JH. Pengaruh Pajanan Benzena terhadap Timbulnya Leukemia Mieloid Akut pada Pekerja yang Terpajan. J Kedokt. 2015;(May):1-14.
19. TualekaAR, Faradisha J, Maharja R. Determination of No Observed Adverse Effect Level Ammonia in White Mice Through CD4 Expression. DoseResponse An Int J. 2018;16(4):1-9.

20. Tualeka AR, Wibrata DA, Ahsan A, Rahmawati P, Russeng SS, Wahyu A, et al. Determination of Highest Dose of Ammonia without Effect at Work Environment Through The Expression of Interleukin-2 Cell in Rattus Norvegicus. Open Acces Maced J Med Sci. 2019;7(6):897-902.

21. Swaen GMH, Amelsvoort L Van, Twisk JJ, Verstraeten E, Slootweg R, Collins JJ, et al. Low Level Occupational Benzene Exposure and Hematological Parameters. Chem Biol Interact. 2010;184(1-2):94-100.

22. Tualeka AR. Toksikologi Industri \& Risk Assessment. Surabaya: Graha Ilmu Mulia; 2013.

23. Tualeka AR, Chahyadhi B. The Relationship Between Ventilation with Excess Cancer Risk of Benzene at The Shoe Home Industry in Romokalisari Surabaya. Indian J Public Heal Res Dev. 2019;10(1):572.

24. Salim RN. Analisis Risiko Kesehatan Pajanan Benzena Pada Karyawan di SPBU " $x$ " Pancoranmas Depok. Fakultas Ilmu Kesehatan, Universitas Indonesia. Universitas Indonesia; 2012.

25. Hayat I. Paparan Benzena Pada Petugas Operator Spbu Di Wilayah Ciputat Tahun 2012. Universitas Islam Negeri Syarif Hidayatullah Jakarta; 2013. 